\author{
斎 藤 浩 三**西島信 人* $^{* *}$ \\ 長 野郁 男 ${ }^{* *}$ 。和 泉 澄 夫***
}

\title{
New Separation Technique for Waste Plastics
}

\section{1. まえがき}

近年におけるプラスチック生産量は，第 1 表1) 亿示す ように，増加の一途をたどり，乙れに伴い1976年におけ るわが国の廃棄量は約 260 万トンにも達し，乙の廃棄プ ラスチック（以下廃プラ）の95\%は燒却および埋立てに たよっている現状である。しかし最近では, 資源の再利 用という点から廃プラの処理技術や再利用技術が強く要 望されるようになり, 溶融再生化, 熱分解によるガス化, 油回収, 乾留, 燃焼エネルギーの活用など, 各方面の研 究, 開発が活発行行なわれている。しかし, 化学的性質 や物理的性質の異なるプラスチックの混合物の形では溶

\author{
Kozo SAITOH, Nobuto NISHIJIMA \\ Ikuo NAGANO and Sumio IZUMI
}

節1䎁 世界各国のプラスチック生産量と消費量

\begin{tabular}{|c|c|c|c|c|c|c|c|c|}
\hline \multirow{2}{*}{ 国 } & & \multirow{2}{*}{ 名 } & \multicolumn{2}{|c|}{ 生産量（千t） } & \multirow{2}{*}{$\left|\begin{array}{r}\mid \text { 生産の伸び } \\
(\%)\end{array}\right|$} & \multirow{2}{*}{$\begin{array}{c}\text { 消 費 量 } \\
(\text { 千 } \mathrm{t}) \\
\text { 1973年 }\end{array}$} & \multirow{2}{*}{$\begin{array}{l}\text { 人口 } \\
\text { (千人) }\end{array}$} & \multirow{2}{*}{$\begin{array}{r}\text { 人口 } 1 \text { 人 } \\
\text { あた } \\
\text { 年間消費 } \\
(\mathrm{kg})\end{array}$} \\
\hline &. & & 1963年 & 1973年 & & & & \\
\hline ア & $x$ & 力 & 4,032 & 13,182 & 320 & 12,502 & 207,050 & 60.4 \\
\hline 日 & & 本 & 1,062 & 6,535 & 620 & 5,598 & 105,220 & 53.2 \\
\hline 西 & ド & ツ & 1,426 & $(6,500)$ & 460 & 4,850 & 59,175 & 81.9 \\
\hline フ & ラ & ス & 508 & 2,550 & 500 & 2,475 & 51,250 & 48.3 \\
\hline イ & 夕 & - & 625 & $(2,340)$ & 370 & 1,900 & 54,078 & 35.1 \\
\hline ソ & & 連 & 528 & $(2,200)$ & 420 & - & - & - \\
\hline 1 & ギ & x & 746 & $1,886 !$ & 260 & 1,830 & 55,566 & 32.6 \\
\hline そ & の & 他 & 1,428 & 8,000 & 560 & - & - & - \\
\hline 合 & & 計 & 10,355 & 43,193 & 420 & & & \\
\hline
\end{tabular}

昭和52年 11 月 8 日本会第59回例会において発表

** 三井金属鉱業(㑣中央研究所

*** 三井金属エンジニアリング林 昭和 52 年 9 月 28 日受理

融成型しても物性が劣化し，また熱分解工程であ種々 のトラブルやコスト高の原因となる。てのように考える と，混合プラスチックをそれぞれ単体に分離し，原材料 にリサイクルするのが最む合理的であり，さらに他の有 効利用技術と組み合わせるととにより大きな効果を生み 出すととができる。

当中央研究所においては, 早くから廃プラ処理の問題 に着目し，てれに関する広範な試験，研究を実施し2), 乾式ならびに湿式分離の新しいプロセスを開発した ${ }^{3) 4) 。 ~}$

一方, 東北大学鉱物処理工学研究室でも活発な研究を 実施しており, 界面活性剂を用いる浮沈分離の新しいセ パレータを発表5), 廃プラの分離に関しては，前記，鉱 
物処理工学研究室と共同研究を実施して, 浮沈分離装置 の工業化スケールアップを行なった6)。

プラスチック生産量では世界最大の米国であ廃プラの 再資源化処理は，官公庁，公共団体，民間会社において 活発に展開されているが，筆者らの開発したプロセスに ついては, PIA (アメリカ・プラスチック学会)の年次 総会7)ならびに, 米国鉱山局, イリノイ工科大学主催の 廃棄物シンポジウム8) において発表した。

\section{2. 分離プロセス概要}

主なプラスチックの比重を，小さいあのから順にあげ てみると

$$
\begin{aligned}
& \text { ポリオレフィン系 } \begin{cases}\mathrm{PP} & 0.90 \sim 0.91 \\
\text { 高密度PE } & 0.94 \sim 0.97\end{cases} \\
& \text { ポリスチレン系 } \begin{cases}\mathrm{PS} & 0.98 \sim 1.10 \\
\mathrm{ABS} \text { 樹脂 } & 0.99 \sim 1.15 \\
\mathrm{AS} \text { 樹脂 } & 1.08 \sim 1.10\end{cases} \\
& \mathrm{PVC}, \text { その他 } \begin{cases}\text { メタリリル樹脂 } & 1.17 \sim 1.20 \\
\text { フェノール樹脂 } & 1.25 \sim 1.30 \\
\text { 硬質 PVC } \\
\text { ユリア樹脂 }\end{cases} \\
& \hline
\end{aligned}
$$

のとおりで, 比重が 1 より小さいポリオレフィン系, 比 重がほぼ 1 に近いポリスチレン系および，比重が 1 より 大きい PVC などのプラスチック群に区別できる。した がって，てれらの比重差を利用すれば，混合プラスチッ クを少なくとも 3 種類の群に分離するととができる。比 重分離の方法としては空気中で分離を行なう乾式法と, 水中あしくは溶液中で行なう湿式法がある。また，比重 が同様のプラスチックについては，表面濡れの性質を調 節してから気泡を導入して浮上法によって分離すること ができる。

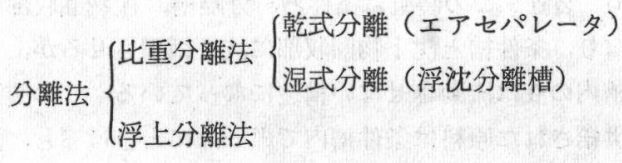

\section{3. 乾式比重分離法}

\section{1 プラスチックエアセパレータ (MIPS-AR)}

空気中で比重分離を行なう方法としては, 従来から風 力分離機が知られており, 空気の流動する方向によって 竪型と横型がある。との種の分離機を用い，各種プラス チックについて試験を実施してみたが, どのように条件 を調節しても高い精度の分離ができなかった。とのよう に分離が不完全となる原因について，あらゆる角度から 検討を加えた結果，分離機の構造に大きな欠陥があるこ とが分った。すなわち，流動空気内に原料混合物を供給 する際に，混合物が単一片になっていないため，数片が

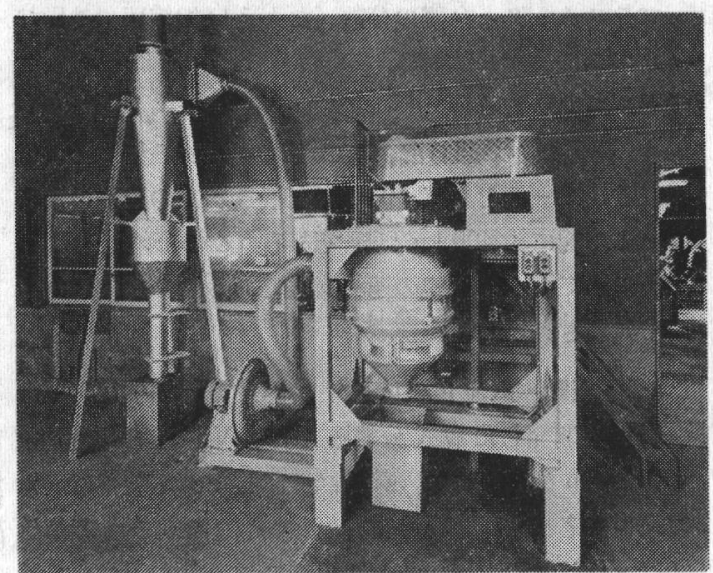

第1図 プラスチックエアセパレータ (MIPS-AR型)

付着したままかたまり状となって落下るしくは飛散する。 したがって，風力分離を精度よく行なうためには，原料 混合物を単一片までときほぐして，均一に流動空気内に 供給するととが必要となってくる。このような観点に立 って装置の試作，改造を行ない，新しい分離機 MIPSAR 型 (Mitsui Plastic Separator-Air Separation 型) を 開発し，第 1 园にこの装置を示した。

a) 構造 分離を行なうケーシングには原料混合物を 単一片までときほぐす目的の分散機構を内蔵している。 ケーシング上部の投入口から原料を供給すると, 高速回 転する円盤の中心部に落下し，遠心力によって円盤外周 から高速度で飛散する。この回転円盤の上にはピンが植 えてあり，円盤上に供給された原料は施回飛散しながら ピンに衝突し，よく分散して外周から均一にはじき出さ れる。飛散した原料は円筒形のケーシングに衝突し，周 壁にそって落下し，ケーシング下部に設置された円錐形 の分離コーンの頂部からすべり落ちる。ケーシング中腹 部には吸気ファンの導管が連結しており, 原料中の軽量 物は吸気による上昇気流によってケーシングの外へ吸引 排出され，比重の大きい物質は分離コーンの下部から落 下する。

b) 分離の実例 実操業の場合には, 破砕機とセパレ 一タは連結して運転する。すなわち, 破砕機で所定程度 まで破砕された原料は気流によって一定量づつセパレー 夕に供給され，連続的に分離が行なわれる。AR 型で処 理される原料の粒度は 1 20 $\mathrm{mm}$ 程度が適当である。 この装置で処理できる混合物としては

塩ビレザーの塩ビと布地の分離 プラスチックすだれから編み糸の分離 ナイロンネットから塩ビの分離 プラスチックから木片，ワラ，紙などの分離 発泡プラスチックの分離 
プラスチックと金属の分離（たとえば銅線屑や鉄片な

よ゙)

などがあげられる。

c) 処理能力 原料混合物の性状によって処理能力は 異なるが，一例として PVC 屑と紙ラベルの分離の場合 は, 1 時間に約 $400 \mathrm{~kg}$ 処理できる。この分離工程は破 砕を含めてすべて乾式の連続操業であるため，安いコス トで処理される。

\section{3-2 振動・気流セパレータ (MIPS-VS)}

新しく開発した乾式分離機 MIPS-VS 型 (Vibrating Separation 型) 装置は, 第 2 図に示した。本装置は, 処 理原料に応じて, ベッドの傾斜角度, 振動数, 空気量 (ベッド盤面の上昇気流）等の最啇な条件が選定される。

a) 構造 VS 型セパレータは, 第 2 図の上部から原 料の供給ホッパー, 摇動ベッドおよびベッドの駆動装置 と上向き気流の発生装置の収納箱から成り立っている。 摇動ベッドの盤面はメッシュ状をなし，乙の網目を通し て，均一に上向き空気が流れていて，傾斜したベッド自 体が往復運動する。原料をベッドの中央付近に供給する と，上昇気流の作用によって，盤面上にかすかに浮いた 状態で往復運動をなし, 比重の重いものは傾斜にさから って上方へ，また，軽いあのは傾斜にしたがって下方へ と分離する。

b) 分離の実例 VS 型で処理される原料の粒度は, 1〜20 mm 程度が適当で，この装置で処理できる混合物 としては

故銅線屑とプラスチック被覆物の分離

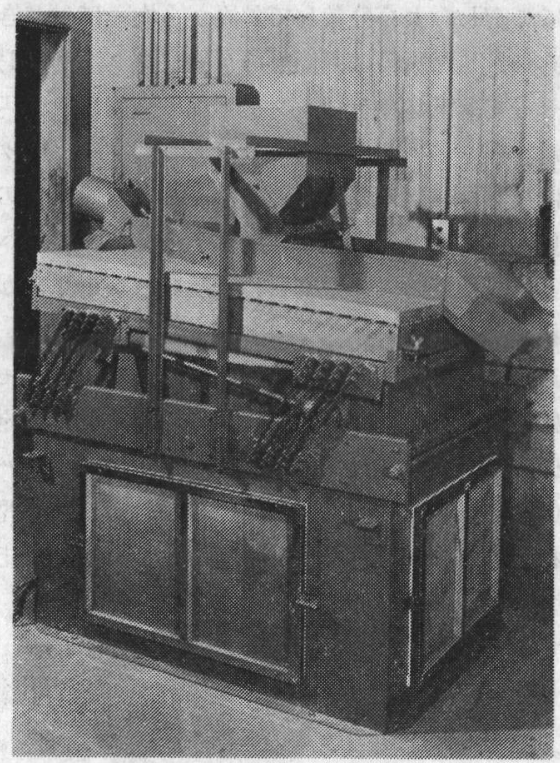

第2 図振動・気流セパレータ (MIPS-VS 型)
PVC 粒と繊維属の分離

プラスチックと土砂の分離

その他比重差のある混合物の乾式分離 などがあげられる。

c) 処理能力 原料混合物の性状によって処理能力は 異なるが，一例として故銅線㞕とプラスチック被覆物の 分離の場合は，1時間に約 $300 \mathrm{~kg}$ 処理できる。

\section{4. 湿式比重分離法}

プラスチック類の砕片を水中に装入すると，プラスチ ック表面が疎水性であるために気泡が接着し，さらに砕 片が複雑な形状を呈する場合には湾曲部や分岐部に気泡 をだきこみ，フィルム状の場合には複数枚が重なり合っ て中間に気泡が介在することあある。このような状態で は水中もしくは溶液中で浮沈分離を行なっても良好な結 果は得られない。東北大学鉱物処理工学研究室において は,プラスチックなどの疎水性物質を水中もしくは溶液 中で高い精度で浮沈分離を行なう新しい技術を開発し た5)。

\section{$4 \cdot 1$ 浮沈分離装置 (MIPS-SI)}

各種プラスチックに対する界面活性剤の湿潤作用につ いて基礎試験を実施し, 陰イオン系界面活性剂としてド デシル硫酸ナトリウム, 陽イオン系としてドデシルアン モニウムアセテート, 非イオン系としてポリオキシェチ レンドデシルエーテルについて湿潤効果を追求した。そ の結果, 水溶液中のイオンの種類, 濃度, 水質, 塩類の 共存などをあわせ考え, 非イオン系の界面活性剤が適当 であることを見出している。この研究結果にもとづき, 汎用プラスチックを用いて分離試験を重ね, 独特の試験 装置を試作した。

a) 装置 この装置は条件槽, 分離槽, 産物回収部よ りなり, 条件槽と沈下物回収部に液を循環させるが, 分 離槽内の液は流動させない構造になっている。この装置 に供給された原料は条件槽内で単一片にときほぐし，液 中に添加した界面活性剂の作用によって親水性化したプ ラスチック片を非流動型分離槽に導き入れて, 比重差に よって液面と槽底に浮沈分離する。

b) スケールアップ 東北大学で試作した小試験機を あとにして3段階のスケールアップを行ない，とのほど 装置の実用化に成功した。第 3 図に分離装置 MIPS-SI 型 (Sink-Float Separation 型) を示した。

槽は長さ $1,700 \mathrm{~mm} \times$ 幅 $380 \mathrm{~mm} \times$ 高さ $1,300 \mathrm{~mm}$ の 大きさをもち，通例の汎用プラスチックは 1 時間に約 $150 \mathrm{~kg}$ 処理するととができる。

c) 分離の実例 比重が 1 より小さいポリオレフィン 系プラスチックを含む混合物を浮沈分離するには, 水中 


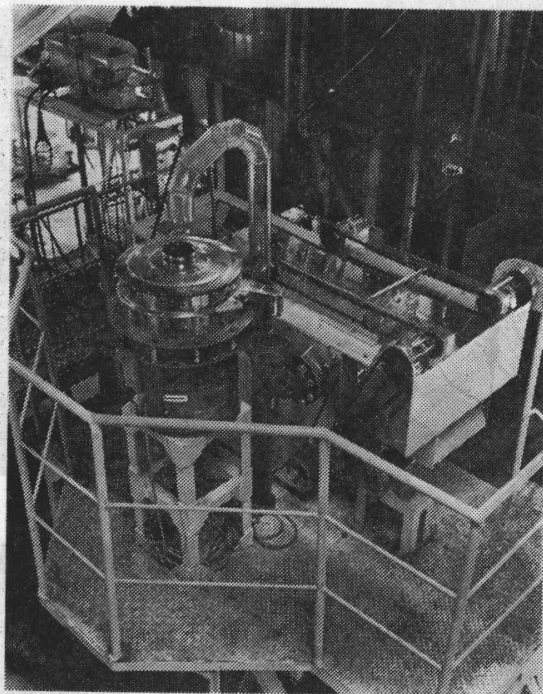

第3 図、湿式比重分離装置 (MIPS-SI 型)

で実施し，比重が 1 よりやや大きいポリスチレン系プラ スチックと $\mathrm{PVC}$ などと分離するには $\mathrm{NaCl}$ すしくは $\mathrm{CaCl}_{2}$ などの塩を添加した溶液中で実施する。この装置 を用いて, PP, PE, PS, PVC, 木片, 紙, アルミ箔など の分離を行なって高い純度の産物を回収することができ た。この場合の能力は 1 時間に $150 \mathrm{~kg} \sim 200 \mathrm{~kg}$ である。

\section{$4 \cdot 2$ MIPS-SI を組入れた実用プラント ${ }^{6)}$}

本装置を用いる廃プラスチック選別プラントのフロー シートを第 4 図，プラントの外観を第 5 図に示した。乙 の選別プラントにおいては，PE フィルムとこれに PS， アルミ箔, 土砂, PVC, セロファンその他の異物を含む 廃プラから PE を選別回収しており, 処理能力は約 350 $\mathrm{kg} / \mathrm{Hr}$ である。

本装置は種々の廃プラの選別に適用可能であり，例え ば自動車の廃充バッテリースクラップ中のプラスチック の選別，一般家庭加ら排出されるワンウェイプラスチッ

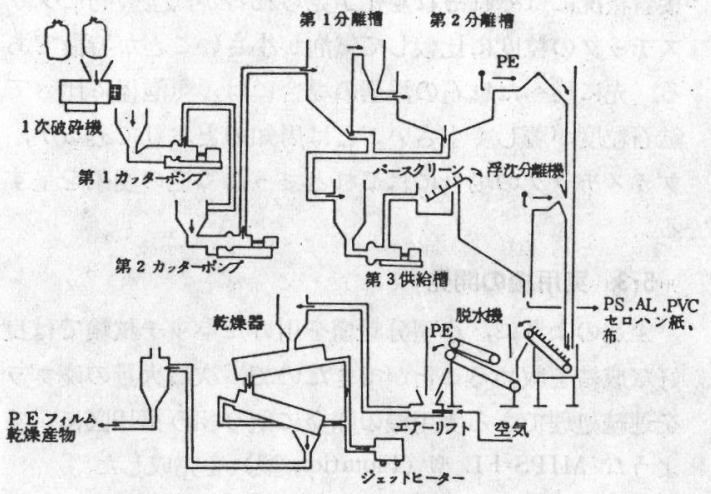

第 4 図 実用プラントのフローシート

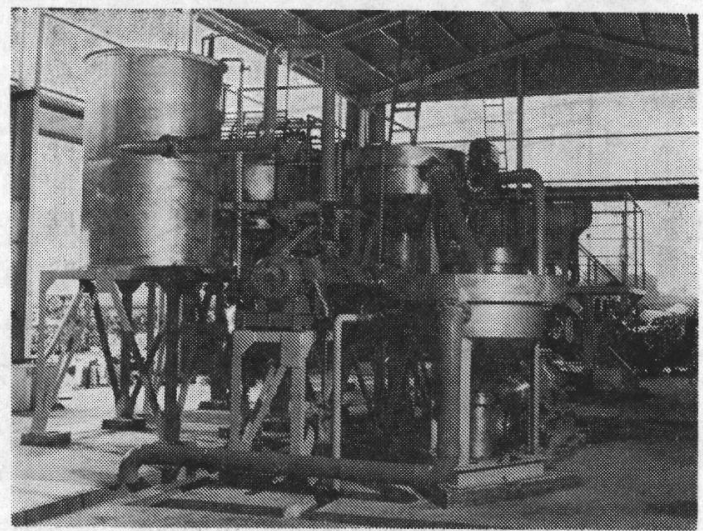

第 5 図 実用プラントの外観

クボトル類の選別などについては良好な実験結果が得ら れている。

\section{5. 浮上分離法}

一般プラスチック類の表面は踈水性を有しており，水 に濡れにくいが，プラスチックの表面性状を詳細に調查 し数多くの基礎研究を実施した結果，プラスチックの濡 れの性状は人為的に調節できるととを見出した。すなわ ち，水中に湿潤剤が存在する場合には，特定のプラスチ ックの表面だけを選択的に疎水性から親水性に変化させ 得ることがわかった。

\section{$5 \cdot 1$ プラスチックの濡れの性状}

接触角の測定には第 6 図のゴニオメータ式接触角测定 器を用いた。測定器本体は照明ランプ, 試料ステージ, 顕微鏡および写真撮影装置よりなる。

測定試料として PP フィルム， PE フィルム， PS シ ート，PVC 薄板をえらび，测定個所をかえて 5 测点で 测定した結果，測定值に若干のバラッキが見られるが，

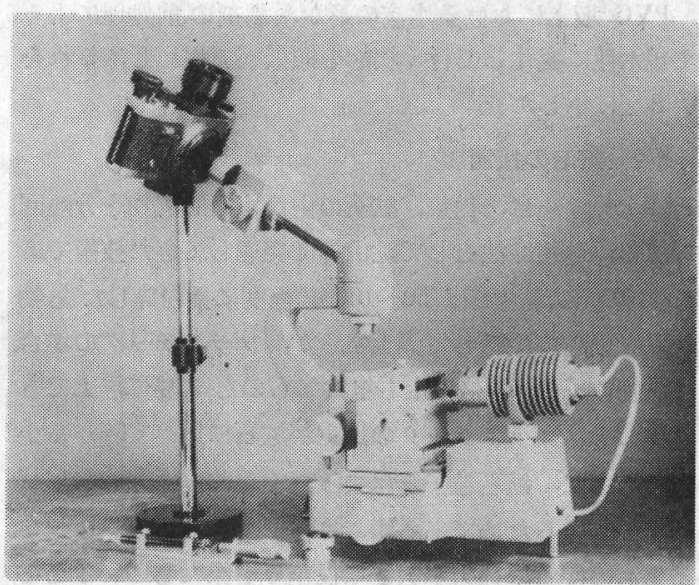

第 6 図 接触角测定装置

Vol. 24, No. 4 ('77-冬) 


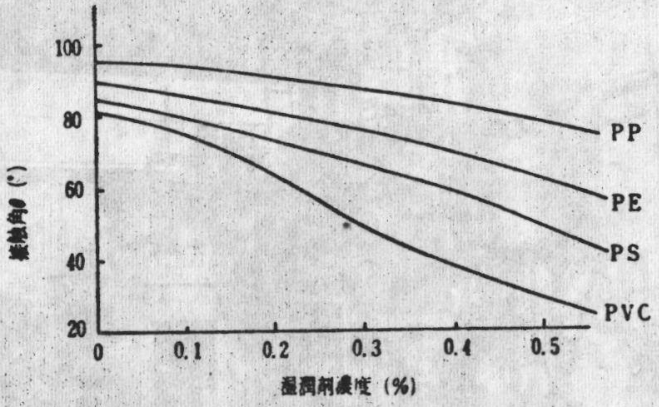

第 7 図 湿潤剤濃度と接触角の関係

平均すると $\mathrm{PP} 96^{\circ}, \mathrm{PE} 90^{\circ}, \mathrm{PS} 86^{\circ}, \mathrm{PVC} 82^{\circ}$ という值 が得られ，いずれあ高い疎水性をもっているととが分る。

これらの試料を用いて数多くの湿潤斉の湿潤効果を接 触角湘定法によって比較検討した結果, ある特定の湿潤 剂だけがプラスチックの種類によって選択的な作用をす るととを見出した。すなわち，リグニンスルホン酸ナト リウムおよび, ケブラチョ, ゼラチン, ニカワ, タンニ ン酸などの有機コロイド類がとくに顕著な選択湿潤効果 を呈することが分った。

上記 4 種類の供試料を種々の濃度の湿潤剂溶液中に浸 漬し，風乾したのち純水の 1 滴を滴下して接触角を測定 した。一例としてリグニンスルホン酸ナトリウムとタン ニン酸の等量混合液を湿潤剤に使用した場合の測定結果 を第 7 図に示したが，湿潤剤濃度が増加するにしたがっ て，4種いずれのプラスチックについてあ接触角が明ら かに減少する。しかもプラスチックの種類によって減少 する程度が異なり，PP は湿潤剤の影響をうりにくいが PE，PS，PVC の順で次第に湿潤剤の作用が大きくなっ ていくことが分る。このような現象は湿潤剂のプラスチ ック表面に対する選択的な吸着にあとづくすのと考えら れ，この点について現在基礎研究を実施中である。

PVC 板上における水滴の形が湿潤剂の前処理によっ て親水性に变化して行く状態を顕微鏡で撮影し，これを 第8図に示した。

\section{$5 \cdot 2$ 気泡の接着}

浮上分離法は，従来，鉱石の中から目的鉱物を分離回 収する浮遊選鉱法として鉱山界で発達してきた技術であ る。鉱石の浮選では $50 \sim 100 \mu$ 程度に微粉砕した 鉱物 粒子を気泡に接着して浮上するが，プラスチックの場合 は鉱物粒子の 100 倍以上す粗大なすのあ容易に浮上でき る。とれはプラスチックの比重が鉱石に比べて著しく小 さく，また，鉣石粒子とはまったく異なった特殊な形状 をむっているためであるが，さらにプラスチックに対す る気泡の接着の仕方が大きな役割りを果たしているあの と考えられる。

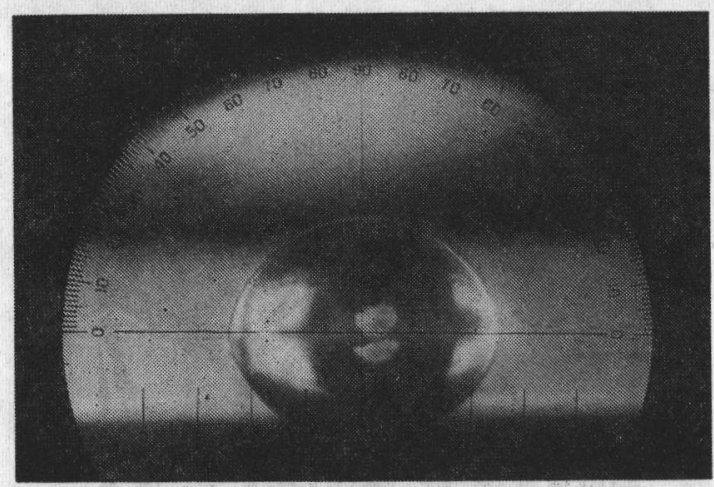

未処理の P V C

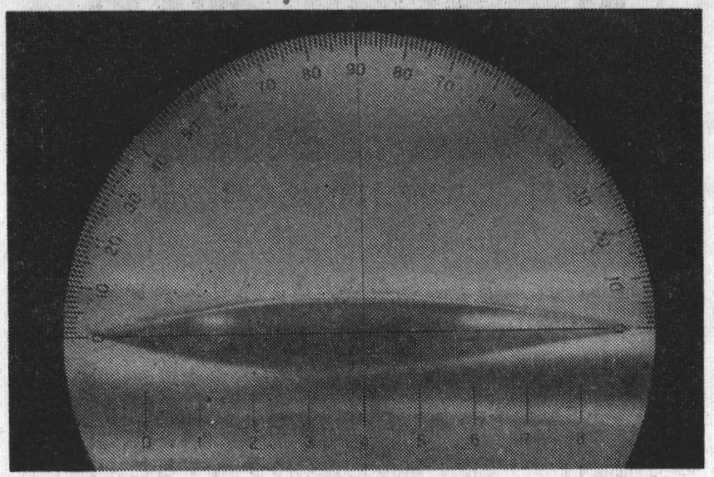

湿潤剂で処理したP V C

第 8 図 PVC 板上の水滴形状の変化

この点を詳細に検討するために気泡の接着状況を顕微 鏡で観察した。

大きさ $10 \times 10 \times 50 \mathrm{~mm}$ の角柱形透明ガラスセルに純 水を満し，乙れにプラスチック小片を入れ，セル底部か ら小気泡を導入し, 気泡がプラスチックの表面に接着し て浮上する瞬間を顕微鏡写真で撮影した。第 9 四の a は ポリスチレン (PS) ペレット， b はポリエステル (PET) フィルム, c は PVC の不規則形粒子に対する気泡の接 着状況を示した。プラスチックの形状によって, 気泡の 接着状況にはそれぞれ変化が見られるが，全般的にプラ スチックの粒度に比較して気泡が小さいことが特徵であ る。先に述べた鉱石の浮選の場合には, 気泡径に比べて 鉱石粒度が著しく小さいととは周知のとおりであるが; プラスチックの場合にはこれとまったく逆の現象を呈す る。

\section{$5 \cdot 3$ 実用機の開発}

上述のように，小型分離槽を用いたバッチ試験では良 好な成績を収めることができたので，次に大量の廃プラ を連続処理できる実用機の開発に取り組み第10図に示す ょうな MIPS-FL 型 (Flotation 型) を完成した。

a) 装置の仕様 FL 型の 1 槽の大きさは幅 $600 \times$ 長さ 


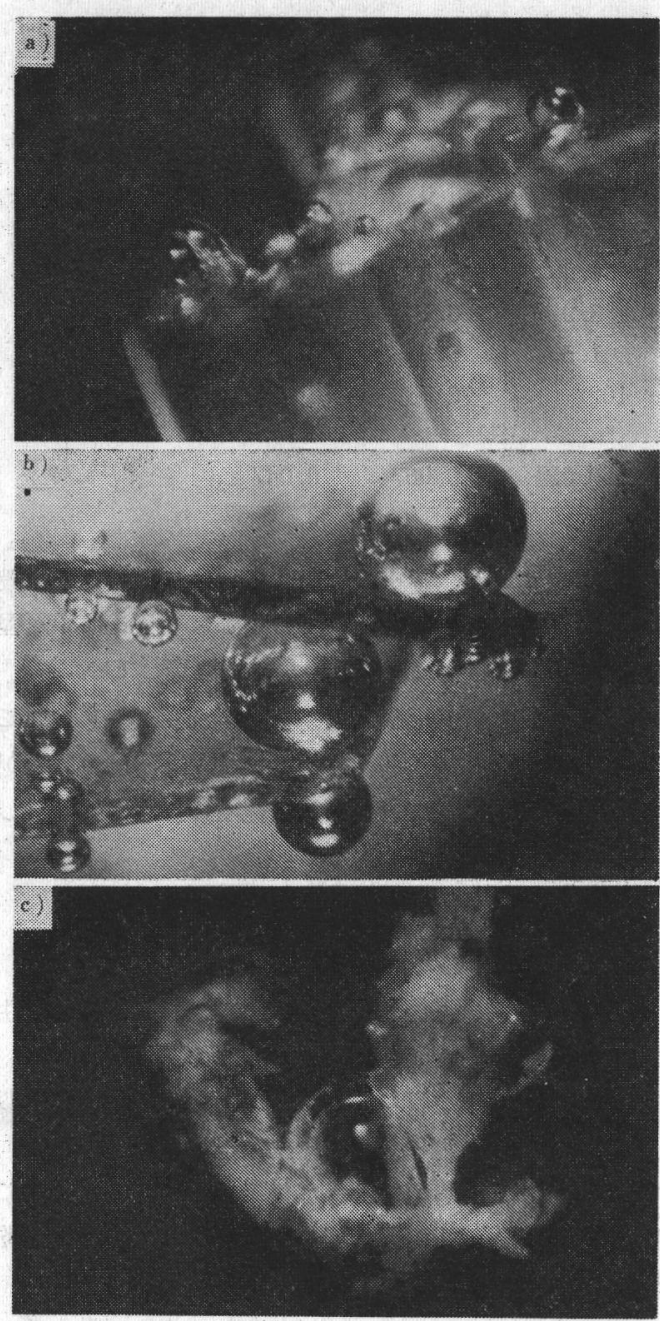

第9図 プラスチックと気泡の接着状況

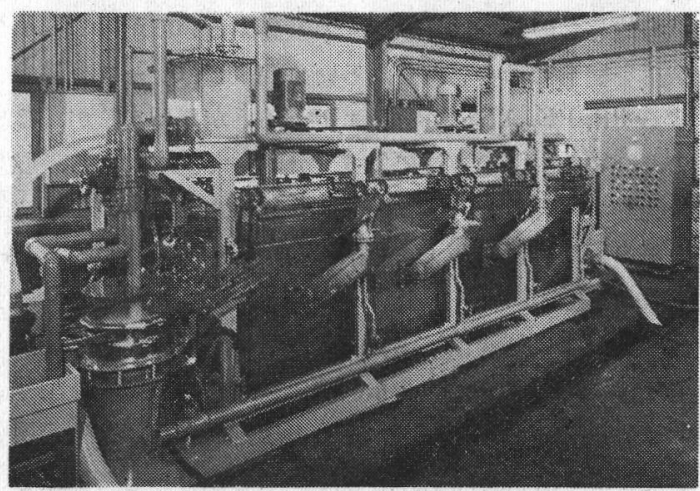

第10図 浮上分離装置 (MIPS-FL型)

$600 \times$ 深さ $900 \mathrm{~mm}$ で標準仕様としては 6 槽を 連結した あのが 1 セットになっている。処理する原料の性状に応 じて槽数を追加することも減らすてともできる。

b) 処理系統 処理原料のプラスチックの種類, 形状, Vol. 24, No. 4 ('77-冬)

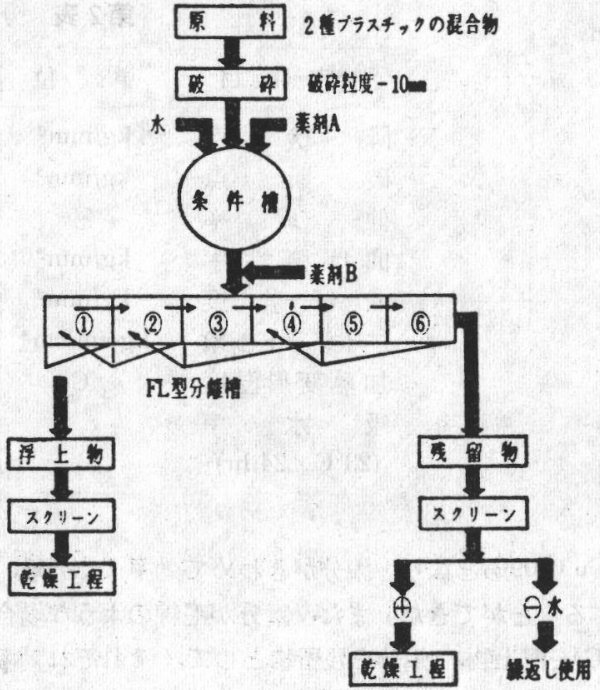

第11図 MIPS-FL 型を用いるフローシートの一例

発生状態はそれぞれ異なっており，てれに応じて処理系 統や条件も異なるが， 2 種プラスチックの混合物を $\mathrm{FL}$ 型で処理する場合の代表的なつローシートを第11図に示 した。この工程における薬剤の使用量はわずかで重金属, COD や BOD などの二次公害のおそれはない。

c) 処理能力 処理する原料の形状によって FL 型の 処理能力は異なるが，粒状プラスチックの場合，6槽を 用いて 1 時間に約 $300 \mathrm{~kg}$ 処理できる。フィルム状，レ ザー状, シート状の場合は処理量は減少する。

\section{$5 \cdot 4$ 分離の実例}

以上のようにして開発したプラスチックセパレータは, 各種の混合プラスチックの分離に広く適用できる。たと えば，都市廃プラから PVC の分離，故銅線被覆くずの 分離, 各種加工くず, 製品くずの分離, ワンウェイ容器 の再生処理, プラスチックからの異物除去, レザー，フ ィルム, シートくずの分離, 樹脂粉を含有する廃液の処 理, プラスチック以外の軽量物質の分離回収などである。

(1) 故銅線の処理

故銅線の線径が比較的太い場合には破砕したのち，ふ るい分け，風力選別，比重選別などを組み合わせると銅 分を分離, 回収できるが, 線径の細い場合には破碎物が 粉状になって従来法では分離できない。また従来の乾式 分離工程で発生するダストの中にも銅分を含むが微細な ために回収する方法がなかった。

このような微細銅粉とプラスチックの混合物は FL 型 によって, 効果的に分離するととができる。Cu $2.5 \%$ と PVC を含むダストを試験に供し，PVCを湿潤剤を用い て抑制し銅粉を浮上した結果，将上物の Cuは84.2\%ま で上昇し，その Cu 採收率 $96.3 \%$ で，残留物の PVC 中 
第 2 表 分離産物の物性測定結果

\begin{tabular}{|c|c|c|c|c|c|}
\hline 測 定 項 目 & 単 位 & 浮上物 & 純品 PP & 残留物 & 純品 PS \\
\hline 降 伏 点 & $\mathrm{kg} / \mathrm{mm}^{2}$ & 3.4 & 3.5 & 4.6 & 4.5 \\
\hline 破＼cjkstart断 & $\mathrm{kg} / \mathrm{mm}^{2}$ & 3.0 & 3.1 & 4.8 & 4.8 \\
\hline 伸 び 率 & $\%$ & 19.2 & 17.8 & 32.3 & 41.6 \\
\hline 曲げ弾性率 & $\mathrm{kg} / \mathrm{mm}^{2}$ & 49.5 & 56.6 & 141.3 & 156.4 \\
\hline 曲 げ 強 度 & $\mathrm{kg} / \mathrm{mm}^{2}$ & 4.4 & 3.9 & 6.1 & 5.9 \\
\hline アイゾッド衝撃 & $\mathrm{kg} \cdot \mathrm{cm} / \mathrm{cm}^{2}$ & 2.1 & 1.5 & 6.8 & 6.8 \\
\hline 加熱変形温度 & ${ }^{\circ} \mathrm{C}$ & 98 & 102 & 78 & 78 \\
\hline 吸水 率 & $\vdots$ & & & & \\
\hline$\left(23^{\circ} \mathrm{C} \times 24 \mathrm{hr}\right)$ & $\%$ & 0.002 & 0.024 & 0.067 & 0.047 \\
\hline
\end{tabular}

の $\mathrm{Cu} 0.09 \%$ となり, 銅分がきわめて効率よく分離, 回 収することができた。また，銅分が毛線のような場合は， PVC を浮上物，銅分を残留物として，それぞれ効率よ く分離, 回収することあできる。

(2) 混合プラスチックの分離

混合プラスチックについては, 湿潤剤や浮上剂を適当 に選択することにより, 各種のプラスチックが分離でき る。

PP と PS からなる製品くずを $10 \mathrm{~mm}$ 以下に破砕し， 湿潤剤と浮上剂の組み合わせ使用によって PP を浮上 分離するととができる。原料は PP 21\%，PS 79\%から なるスダレ状のもので, PP を浮上した結果, 浮上物の PP 99\%，残留物の PS 98\%という高い純度の分離物が 採取でき, 回収率はいずれも95\%以上であった。てのよ うにして得られた分離産物で試験片を作製し, 各種の物 性試験を行なった結果は, 第 2 表のとおりで, 純品と比 較してほとんど差異がなく，乙れを見ても再生利用に好 適なととがわかる。

\section{(3) 写真フィルムの分離}

写真フィルムの基材には, ポリエステル (PET), セル ローズトリアセテート (TAC)の 2 種類が用いられ, PET はレントゲン用, $8 \mathrm{~mm}$ シネ用に, TAC は胦画用, 35 $\mathrm{mm}$ フィルム用に供用されている。フィルム工場で発生 するロス品や廃棄フィルムから銀を回収するてとはてれ まであ行なわれていたが，脱銀したあとのフィルムくず はPET と TAC の混合物であるため 再生利用するてと ができないまま焼却むしくは埋立てていた。

脱銀工程から出て来るフィルムくずから PET を分離, 回収するために FL 型を適用した。このフィルムくずの サイズは $8 \mathrm{~mm}$ 以下で，その成分は PET $94.8 \%$, TAC $5.2 \%$ である。湿潤剤を用いて PET を選択的に親水性 にして TAC を浮上した結果, 残留物中の PET の純度 99.95\%，その採収率 $99.2 \%$ の成績を得た。

(4) 工程中間物の回収

$\mathrm{PVC}$ の製造工程では, PVC 粉末とシリカ粉末を含む
廃水を発生するが，従来は沈殿池を用いて固形物を沈殿 させ，上澄水を流していた。乙の沈降スラッジは30\%程 度の PVC を含むが純度が低いために廃棄していた。

PVC 33.5\%， $\mathrm{SiO}_{2} 66.5 \%$ を含むスラッジを $\mathrm{F} \mathrm{L}$ 型に 供給し試験した結果, 浮上物としてPVC 99\%のののが 採収率96.8\%で回収できた。この純度のものは製品とし て十分供用するてとができる。

\section{6. 各穤分㒕法の组合せ}

以上の実施例は，いずれも FL 型を用いる浮上分離法 によるあのを示したが，比重値に差異のある混合物は， 前工程で比重分離を行ない，乙てで得られる比重の類似 したプラスチック群に対して浮上分離法を適用すると両 方式の特徵が活かされて大きな効果を発揮する。つぎに 湿式比重分離と浮上分離の組み合わせおよび，湿式と乾 式比重分離の組み合わせの実例をあげる。

a) バッテリースクラップ 自動車の廃棄バッテリー を脱酸破砕し，グリットターミナルなどの鉛合金を比 重分離したのち，20メッシュの振動ふるいにかけてペー ストを網下に除去した。ふるいの網上にはケースを構成 する $\mathrm{PP}, \mathrm{PE}, \mathrm{ABS}$ 樹脂, エボナイトが残留するが，乙 の混合物をつぎの方法によって分離した。すなわち，混 合物を SI 型に供給し, 湿潤剤を含む水中において浮沈 分離を行ない比重が 1 より小さい PP, PE を浮上物とし, これより重い ABS 樹脂，エボナイトを沈下物とした。 浮上物は FL 型 4 槽に供給し湿潤剤を用いて PE を抑制 してPP を浮上させ，また，沈下物は別系統の FL 型 4 槽に供給して湿潤剤でエボナイトを抑制し，浮上剤を用 いて ABS 樹脂を浮上分離した。このようにして採取さ れた産物の純度はいずれも96〜98\%古く再生利用に好 適なあのであった。

b) ワンウェイプラボトル 一般家庭から排出される プラボトルを 5 10 mm 亿破砕して 分離試験の原料 と した。乙の原料中には PE, PVC, 紙ラベルを含み, まず 
初めに SI 型で水を用いて PE を浮上物として回収し， 沈下物を振動 スクリーンで脱水し，気流乾燥したのち AR 型に供給してエアセパレーションを行ない，紙を飛 散した結果, 純度99\%のPVC が回収できた。原料中に $\mathrm{PS}$ を含を場合には SI 型で $8 \%$ 濃度の $\mathrm{NaCl}$ 溶液を用 いて PS を浮上物として分離, 回収できる。

\section{7. むすび}

廃プラスチックを再生活用するには，混合物を分離す る工程が必要であるが，乙れまでは有効適切な方法が知 られていなかった。しかしプラスチックのあっている性 質について詳細な検討を重ねた結果, 固体分離を行なう 上に有力な手がかりとなる新しい事実を見い出した。す なわち，水中に湿潤剤が存在する場合，乙れが特定のプ ラスチックだけに作用して選択的に疎水性から親水性に 変化することが分かった。こてに小気泡を導入すれば踈 水性プラスチックに気泡が接着し，その浮力によって水 面上浮上し，ほかの親水性プラスチックと容易に分離 することができる。また，湿潤剤の存在下でプラスチッ クの表面疎水性をとり除いたのちに，水中むしくは溶液 中で浮沈分離を行なうという新しいプロセス屯開発した。

このようなプロセスの開発にとあなって，プラスチッ クの分離に適する浮上分離装置や浮沈分離装置もとくに 設計, 製作され，さらに従来の乾式分離法にはなかった 新しいエアセパレータも開発された。これらの方法を組
み合わせることによって，各種廃プラをきわめて効率よ く, しかむ工業規模で分離できるようになった。

なお，本稿でとりあげた分離技術ならびに装置につい てはすでに50件の特許を出願した。 本研究を実施するにあたり, 東北大学資源工学科下飯 坂教授から格別のご指導を晹わり, 同研究室の鴻巣博士, 林助手にあ熱心など援助をいただいた。また，三井金属 煍中央研究所田中所長加絶えざるご指導とで鞭䞨を賜 り，第一研究室の諸氏からで協力をいただいた。こてに 付記して深く謝意を表する。

\section{参考 文 献}

1）—：1973年プラスチック工業統計資料集，プラス チック Vol. 25, No. 6, (1974)

2) 田中宏：浮選, 51, (1973) p. 49 57

3）斉藤浩三, 長野有男, 和泉澄夫：プラスチックエー ジ, Vol. 20 (1976，10月) p. 99 103

4）斎藤浩三: 表面, Vol. 13, No. 6 (1975), p. 344 353

5）下飯坂潤三，鴻栄涁，林雄造：日鉱，Vol. 90, No. 1042 (1974) p. $775 \sim 779$

6）下飯坂潤三，鴻栄涁，林雄造，斎藤浩三：日 鉱, Vol. 92, No. 1064 (1976) p. 675 679

7) — : PIA Bulletin, Vol. 4, No. 5 (1976)

8) K. SAITOH et al: Proceedings of the 5th Mineral Waste Utilization Symposium, April (1976), p. 322 $\sim 328$ 